Mariusz Tomczyk, Tomasz Kościelecki

Akademia Obrony Narodowej

m26@poczta.onet.pl tel.505 361052

\title{
ROLA GAZU W BEZPIECZEŃSTWIE ENERGETYCZNYM POLSKI
}

\section{Streszczenie}

Gaz ziemny staje się coraz bardziej istotnym surowcem energetycznym na świecie, a rynki gazu należą do najszybciej zmieniających się segmentów globalnego handlu paliwami kopalnymi. Polska obecnie pozyskuje gaz ziemny z własnych złóż gazu oraz poprzez import. W pracy przedstawiono, jak wygląda bezpieczeństwo energetyczne Polski. Wykazano również, że konieczne jest zwiększenie technicznych możliwości pozyskania gazu (gazoport), a także jednoznaczne określenie wielkości niekonwencjonalnych zasobów gazu w Polsce.

Słowa kluczowe: gaz ziemny, gaz łupkowy, bezpieczeństwo energetyczne

\section{Role of energy gas safety polish}

\begin{abstract}
Natural gas is becoming an increasingly important energy resource in the world and gas markets are among the fastest-changing segments of the global trade in fossil fuels. Poland currently obtains natural gas from its own gas fields and through imports. The study shows how it looks Polish energy security. It was also shown that it is necessary to increase the technical possibilities of obtaining gas (LNG terminal), and the clear determination of the size of unconventional gas resources in Poland.
\end{abstract}

Key words: natural gas, shale gas, energy safety 
Wraz z rozwojem cywilizacji systematycznie rośnie zapotrzebowanie na energię, intensywnie od początku XIX-wiecznej rewolucji przemysłowej, a jeszcze gwałtowniej po II wojnie światowej. W ostatnich dziesięcioleciach daje się zauważyć wzrost zapotrzebowania na gaz ziemny na świecie. Surowiec ten znajduje liczne zastosowanie w wielu gałęziach gospodarki - zarówno dla potrzeb przemysłu, sektora usług, jak i w gospodarstwach domowych. W ciągu ostatnich 20 lat średnie zużycie energii na osobę na świecie wzrosło o $40 \%$, przy czym w Chinach aż o $150 \%$, Indiach o $90 \%$, w USA o $20 \%$, a w krajach Unii Europejskiej o $7 \%^{1}$. Bilans energetyczny świata (rys. 1) pokazuje, że najważniejszym surowcem energetycznym jest ropa naftowa, która pokrywa ponad 30\% zapotrzebowania na energię pierwotną. Drugim surowcem energetycznym jest węgiel, którego wykorzystywanie budzi wiele kontrowersji $\mathrm{z}$ powodu wysokiej emisji $\mathrm{CO}_{2}$ i innych gazów cieplarnianych. Miejsce trzecie zajmuje błękitne paliwo, czyli gaz ziemny z ponad 20\% udziałem w bilansie globalnym, a jego udział i znaczenie lawinowo wzrastają.

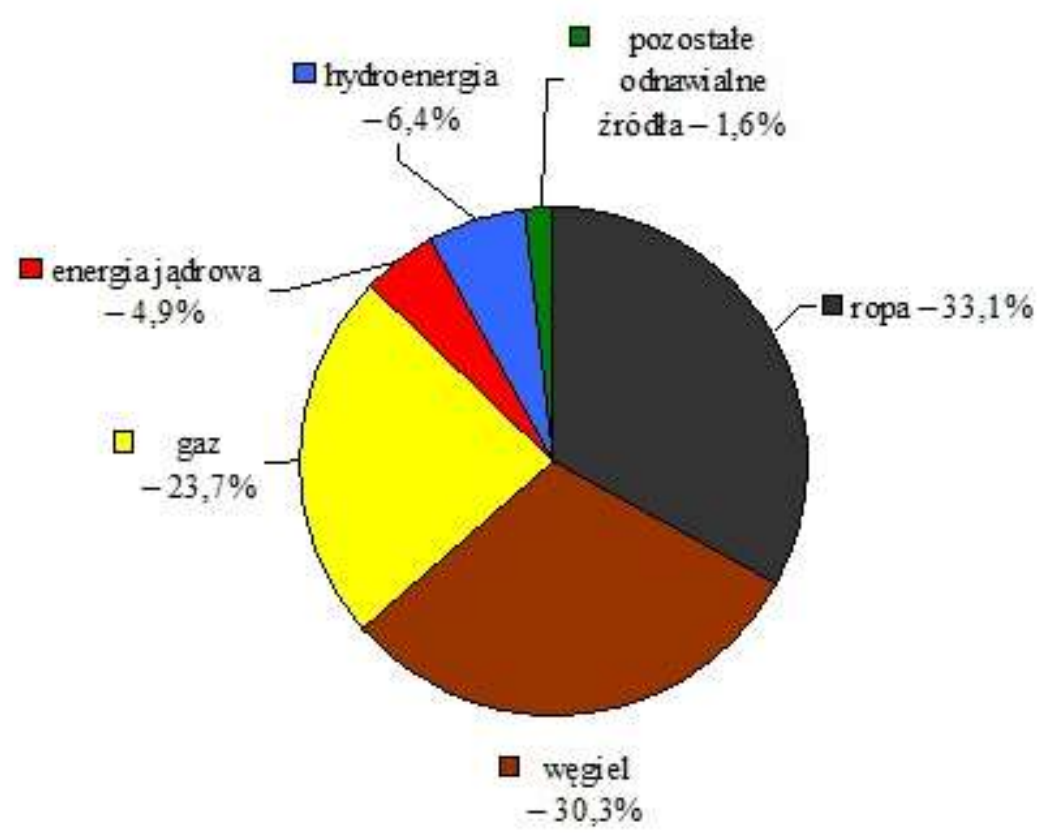

Rys. 1. Energia z poszczególnych źródeł na świecie

Źródło: http://ziemianarozdrozu.pl/artykul/2184/kolejny-przeglad-energetyczny-bp-statistical-review-ofworld-energy-2012 dostęp 12.04.2016

\footnotetext{
${ }^{1}$ http://infolupki.pgi.gov.pl/gaz-ziemny/gaz-ziemny-surowiec-strategiczny dostęp 12.04.2016
} 
Niektóre prognozy długoterminowe przewidują, że wkrótce w bilansie energetycznym świata gaz ziemny zdeklasuje nie tylko węgiel, ale także ropę naftową. $Z$ prognoz Międzynarodowej Agencji Energetycznej MAE (ang. IEA - International Energy Agency) wynika, że do 2019 roku globalny popyt na gaz będzie rósł średnio na rok o 2,2\% ${ }^{2}$. Uzupełniającą rolę w bilansie energii pełnią: energia jądrowa oraz OZE - odnawialne źródła energii.

W miksie energetycznym Polski mamy nieco inne proporcje. $\mathrm{Z}$ rys. 2 wynika, że niekwestionowanym numerem 1 jest węgiel (kamienny 53\%, brunatny 34\%), który zaspokaja ponad $80 \%$ potrzeb różnych dziedzin gospodarki. Na 2 miejscu plasuje się gaz ziemny oraz biomasa, których udział w bilansie energetycznym wynosi po 4\%. Trzecim największym źródłem energii elektrycznej w Polsce są produkty naftowe (2\%) oraz wodne (2\%).

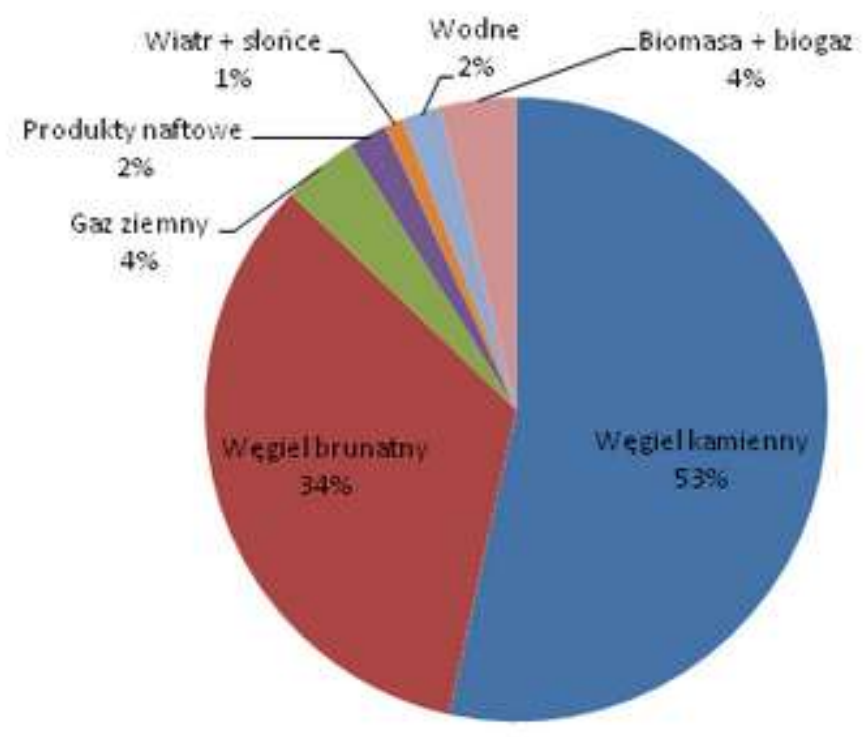

Rys. 2. Struktura udziału w produkcji energii elektrycznej w Polsce Źródło: http://tozalezy.pl/index.php/energetyka-jadrowa-v-2-4/ dostęp 12.04.2016

\footnotetext{
${ }^{2}$ http://www.pb.pl/3726560,46378,popyt-na-gaz-ziemny-bedzie-rosl-wolniej dostęp 12.04.2016
} 
W naszym kraju już chyba nikt nie wyobraża sobie życia bez elektryczności, jednak specjaliści przypominają, że z każdym rokiem znacząco wzrasta prawdopodobieństwo wystąpienia ograniczeń $\mathrm{W}$ dostawach prądu oraz potężnych awarii systemu elektroenergetycznego zwanych blackouts. Jak przyznał krajowy Urząd Regulacji Energetyki, „dzisiaj odbiorcy końcowi maja coraz mniejsze poczucie bezpieczeństwa w zakresie dostaw energii elektrycznej. Traca zaufanie do wielkiej energetyki $i$ chca zapewnić sobie bezpieczeństwo dostaw we własnym zakresie ${ }^{3}$.” Jedną z wielu przyczyn tego stanu rzeczy może być brak możliwości zaspokojenia wzrastającego zapotrzebowania gospodarki na energię elektryczną, mimo że Polska znajduje się na drugim miejscu w UE pod względem niezależności energetycznej, co zawdzięczamy własnym złożom węgla. Wykorzystywanie węgla jest krytykowane przez ekologów i unijnych polityków, ale z jego przetworzenia pochodzi aż 87\% energii elektrycznej wytwarzanej w naszym kraju (rys. 2).

W Polsce prognozowany wzrost zapotrzebowania na energię pierwotną, w okresie od 2010 do 2030 roku wyniesie ponad 20\%, przy jednoczesnym zmniejszeniu udziału węgla w produkcji energii elektrycznej do poziomu około $60 \%{ }^{4}$.

\section{BEZPIECZEŃSTWO ENERGETYCZNE POLSKI - GAZ ZIEMNY}

Definicja bezpieczeństwa energetycznego została przedstawiona $\mathrm{w}$ ustawie $\mathrm{z}$ dnia 10 kwietnia 1997 - Prawo energetyczne ${ }^{5}$ jako „stan gospodarki umożliwiający pokrycie bieżącego i perspektywicznego zapotrzebowania odbiorców na paliwa i energię w sposób technicznie i ekonomicznie uzasadniony, przy zachowaniu wymagań ochrony środowiska”. Bezpieczeństwo energetyczne charakteryzuje szereg wskaźników, z których każdy dotyczy innego wymiaru. Wskaźniki te muszą być analizowane i interpretowane jako całość, ponieważ mają charakter komplementarny. Do wskaźników tych zalicza się :

\footnotetext{
${ }^{3}$ http://www.ure.gov.pl/pl/urzad/informacje-ogolne/aktualnosci/3586,Blackout-a-Krajowy-SystemEnergetyczny-Prezes-URE-o-bezpieczenstwie-energetyczny.html dostęp 12.04.2016

${ }^{4}$ http://infolupki.pgi.gov.pl...op. cit dostęp 12.04.2016

${ }^{5}$ Ustawa z dnia 10 kwietnia 1997 r. Prawo energetyczne, Dz. U. 1997 Nr 54 poz. 348 z późn, zm.

${ }^{6} \mathrm{R}$. Riedel, Bezpieczeństwo energetyczne we wspótczesnej securitologii (w:) Bezpieczeństwo energetyczne Europy Środkowej, red. P. Mickiewicz, P. Sokołowska, Wydawnictwo Adam Marszałek, Toruń 2010, s. 20 - 21.
} 
- udział importowanych paliw energetycznych w bilansie energetycznym;

- stopień dywersyfikacji: źródeł, kanałów przesyłu, surowców energetycznych, z których produkowana jest energia;

- stabilność dostaw (czynnik tranzytowy, polityczny);

- udział energii pozyskiwanej ze źródeł odnawialnych w ogólnym bilansie energetycznym;

- cena energii końcowej bądź płacona za surowiec, jak również jej dynamika oraz wpływ na gospodarkę (przedsiębiorstwa, gospodarstwa domowe);

- wielkość, wystarczalność i udział rezerw paliw energetycznych;

- wielkość, wystarczalność i udział rezerw surowców energetycznych będących we własnej dyspozycji;

- przepustowość interkonektorów z innymi systemami energetycznymi (jak również możliwości i gotowość do dzielenia się surowcami energetycznymi podmiotów zewnętrznych);

- niezawodność sieci energetycznych (elektroenergetycznych, transportowych) sprawność ich eksploatacji i eliminowania niesprawności;

- efektywność energetyczna;

- koncentracja przemysłów energochłonnych;

- możliwości wdrożenia zobowiązań międzynarodowych związanych pośrednio bądź bezpośrednio z energetyką;

- adekwatność priorytetów strategii energetycznej i ich kompatybilność z priorytetami wyrażonymi $\mathrm{w}$ dokumentach wyższej rangi (np. unijny pakiet klimatyczno energetyczny);

- systematyczna realizacja celów strategii energetycznych;

- odpowiednie nakłady inwestycyjne i inne (ekonomiczne, polityczne) uwzględniające przyszły popyt wewnętrzny na energię. 


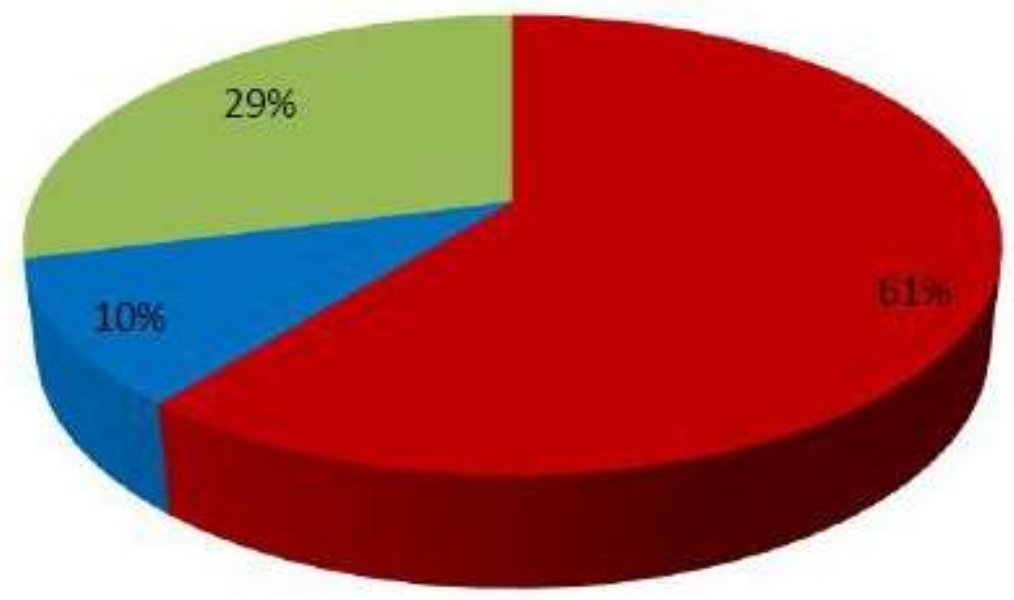

- Gazprom Inne źródła zagraniczne ZŹródła krajowe

\author{
Rys. 3. Źródła dostaw gazu na rynek polski \\ Źródło: http://www.egospodarka.pl/85219,Rynek-gazu-w-Polsce-kierunki-rozwoju,1,56,1.html \\ dostęp 13.04.2016
}

Polska pozyskuje gaz ziemny $\mathrm{z}$ własnych złóż gazu oraz poprzez import. Rys. 3 przedstawia źródła dostaw gazu na polski rynek. Mimo importu dominującej części zużywanego gazu (61\%), Polska dzięki własnym złożom gazu ziemnego ma największą, spośród krajów sąsiadujących, niezależność w zakresie zaspokojenia dostaw tego paliwa. Ze względu na obecną strukturę dostaw gazu do Polski, zdecydowana jego większość pochodzi z jednego źródła, co wystawia Polskę na poważne ryzyko wahań cenowych rosyjskiego gazu i ma wpływ nie tylko na gospodarkę Polski, ale również na jej bezpieczeństwo energetyczne.

Gaz jest przesyłany do Polski trzema gazociągami: gazociągiem orenburskim, gazociągiem Zorza Polarna oraz gazociągiem jamalskim. Są to gazociągi biegnące przez Ukrainę i Białoruś. Jest to istotne gdyż poza dywersyfikacją źródeł (kierunku dostaw) jest bardzo istotnym przebieg gazociągu, tj. układ krajów tranzytu. Z przebiegu kryzysu gazowego z przełomu 2008 i 2009 roku, tj. konfliktu gazowego pomiędzy Ukrainą i Rosją, Polska poniosła najmniejsze straty wśród innych krajów europejskich (UE). W ramach 
długoterminowego kontraktu jamalskiego Polska otrzymuje $8 \mathrm{mld} \mathrm{m}^{3}$ gazu rocznie? W trakcie gazowego konfliktu pomiędzy Rosją i Ukrainą nie zaprzestano tych dostaw gdyż były kierowane poprzez gazociąg jamalski przechodzący przez Białoruś. Jednak obecna sytuacja polityczna pomiędzy Rosją a Unią Europejską spowodowana sytuacją na Ukrainie oraz nałożone obustronne sankcje gospodarcze skłaniają do zastanowienia nad bezpieczeństwem dostaw gazu dla Polski.

Popyt na gaz ziemny w Polsce jest tworzony w największej części przez przemysł (zakłady azotowe, hutnictwo, energetyka) i to przemysł jest w największym stopniu uzależniony od dostaw gazu do Polski. Rys. 4 przedstawia strukturę konsumpcji gazu ziemnego w Polsce.

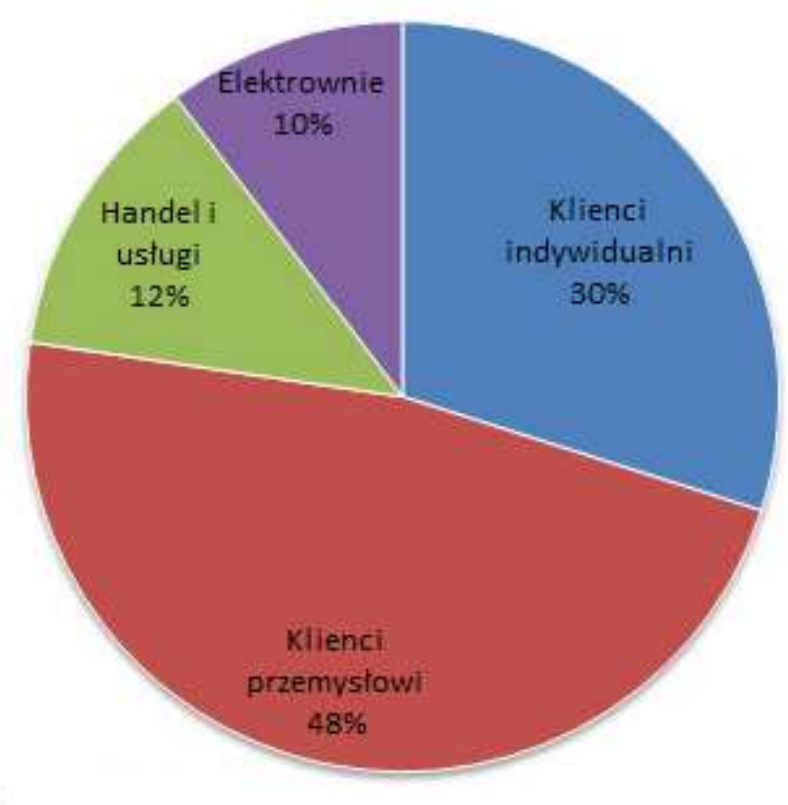

Rys. 4. Struktura konsumpcji gazu ziemnego w Polsce w 2010 roku.

Źródło: http://weglowodory.pl/rynek-gazu-usa/ dostęp 14.04.2016

Drugą, co do wielkości grupą konsumującą gaz ziemny w Polsce są klienci indywidualni. Najmniejszymi grupami podatnymi na wahania dostaw gazu są elektrownie oraz sektor handlowo-usługowy.

\footnotetext{
${ }^{7}$ A. Wandzik, Gaz jako element bezpieczeństwa energetycznego kraju, Gdańska Fundacja Kształcenia Menedżerów, Warszawa 2008, s. 5
} 


\section{DYWERSYFIKACJA DOSTAW GAZU DLA POLSKI}

W naszym kraju często mówi się o potrzebie dywersyfikacji źródeł zaopatrzenia na gaz. Tymczasem zapomina się, że słowo dywersyfikacja ma szersze znaczenie. Jak podkreśla prof. Roman Ney z Polskiej Akademii Nauk „...dywersyfikacja oprócz zwiększenia liczby dostawców, oznacza także zróżnicowanie metod dostaw i - co najważniejsze - dróg transportu..." ${ }^{, \mathrm{W}}$ celu umożliwienia dywersyfikacji dostaw gazu w styczniu 2003 r. zawarto porozumienie między rządem polskim i rosyjskim zakładające redukcję przewidywanych dostaw o 35\%. Dzięki temu do 2020 r. PGNiG SA wydatkuje na dostawy gazu z Rosji ok. 5 mld USD mniej niż oczekiwano. Uzgodniono również wydłużenie okresu trwania kontraktu o dwa lata, do 2022 r. Oznacza to, że Polska w latach 2003 - 2022 sprowadzi z Rosji 161,4 $\mathrm{mld} \mathrm{m}^{3}$ gazu ${ }^{9}$. Zgodnie z przyjętym porozumieniem, dostawy gazu rosyjskiego do Polski będą realizowane w następujących terminach i wielkościach ${ }^{10}$ :

- w latach 2004-2005 ok. 7 mld $\mathrm{m} 3$ rocznie,

- w latach 2006-2007 ok. 7,1 mld m3 rocznie,

-w latach 2008-2009 ok. 7,3 mld m3 rocznie,

- w latach 2010-2014 po 8 mld m3 rocznie,

- w latach 2015-2022 po 9 mld m3 rocznie.

Uzyskana skala redukcji zakupu gazu w ramach kontraktu rosyjskiego pozwoli Polsce przynajmniej w części na zdywersyfikowanie dostaw gazu.

\footnotetext{
${ }^{8}$ D. Malinowski, A. Wanok Potentat przez wyzwaniem, Nowy Przemysł nr 9 (125), wrzesień 2008

${ }^{9}$ http://www.rmf24.pl/ekonomia/news-35-proc-redukcja-dostaw-rosyjskiego-gazu,nId,201682 dostęp 14.04 .2016

${ }^{10}$ M. Lewandowska, Gaz spotowy, czyli żaden. Jak doszło do afery z Euralem?, Magazyn „Nafta \& Gaz Biznes", grudzień 2003.
} 
Ponadto Polska podjęła szereg działań obejmujących następujące możliwości dostaw gazu:

1. Właściwa polityka taryfowa, zachęcająca do inwestowania w infrastrukturę liniową (przesył i dystrybucja gazu),

2. Budowa terminalu do odbioru gazu skroplonego,

3. Zawarcie na warunkach rynkowych kontraktów na zdywersyfikowanie dostawy gazu ziemnego dla terminalu do odbioru gazu skroplonego oraz z kierunku północnego,

4. Stworzenia polityki zrównoważonego gospodarowania krajowymi zasobami gazu umożliwiającej rozbudowę bazy rezerw gazu ziemnego na terytorium Polski,

5. Realizacja inwestycji umożliwiających zwiększenie wydobycia gazu ziemnego na terytorium Polski,

6. Dywersyfikacja dostaw poprzez budowę systemu przesyłowego umożliwiającego dostawy gazu ziemnego z kierunku północnego, zachodniego i południowego oraz budowa międzysystemowych realizujących w pierwszej kolejności postulat dywersyfikacji źródeł dostaw,

7. Pozyskiwanie przez polskie przedsiębiorstwa dostępu do złóż gazu ziemnego poza granicami kraju,

8. Wsparcie inwestycji infrastrukturalnych $\mathrm{z}$ wykorzystaniem funduszy europejskich,

9. Usprawnienie mechanizmu reagowanie w sytuacjach kryzysowych,

10. Zabezpieczenie interesów państwa w strategicznych spółkach sektora gazowego,

11. Stosowanie zachęt inwestycyjnych do budowy pojemności magazynowych (poprzez odpowiednią konstrukcję taryf oraz zapewnienie zwrotu na zaangażowanym kapitale),

12. Działania legislacyjne, mające na celu likwidację barier inwestycyjnych, W szczególności w zakresie dużych inwestycji infrastrukturalnych (magazyny, infrastruktura LNG, tłoczenia gazu, etc.) oraz inwestycji liniowych,

13. Kontynuacja prac pilotażowych udostępnienia metanu ze złóż węgla kamiennego ${ }^{11}$.

\section{GAZ LNG}

LNG (ang. Liquefied Natural Gas) jest to skroplony gaz ziemny. Szansą na zdywersyfikowanie dostaw gazu jest umożliwienie odbierania dostaw gazu skroplonego droga morską. 19 sierpnia

\footnotetext{
${ }^{11}$ Polityka energetyczna Polski do 2030 roku, Załącznik do uchwały nr 202/2009 Rady Ministrów z dnia 10 listopada 2009 r., Ministerstwo Gospodarki
} 
2008 r. Rada Ministrów podjęła uchwałę, w której budowa terminalu LNG uznana została za inwestycję strategiczną dla interesu naszego kraju, zgodną z planami dywersyfikacji źródeł i dróg dostaw gazu ziemnego ${ }^{12}$. Budowa terminalu LNG pozwoli zaspokoić zwiększone zapotrzebowanie na gaz w Polsce, a także umożliwi jego sprzedaż do innych krajów.

Pomimo, iż obecna wartość rynku obrotu gazem przekracza pół biliona dolarów rocznie, handel tym surowcem ograniczał się dotychczas do skali regionalnej ${ }^{13}$. Wynika to z konieczności budowy systemu rurociągów, którymi transportowany jest gaz. Dzięki technologii LNG możliwym stało się zakupienie gazu u odbiorców dotąd nieobecnych na rynku. Największym eksporterem skroplonego gazu na świecie jest Katar (rysunek 5), z którym Polska podpisała kontrakt na dostawy LNG.

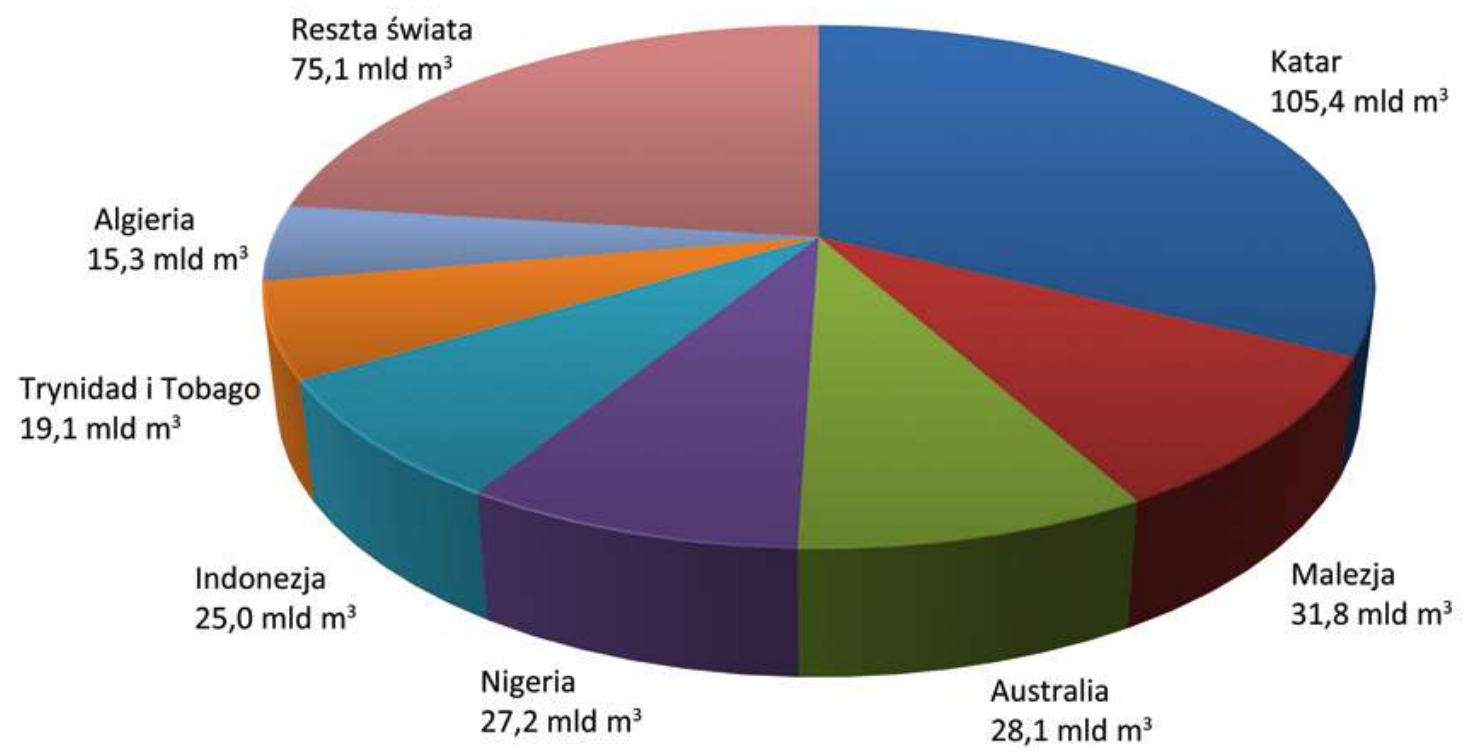

Rys. 5. Najwięksi eksporterzy skroplonego gazu ziemnego na świecie w 2012 roku Źródło:

http://wydawnictwo.inzynieria.com/cat/93/mag_id/9/art/36914/w/167/a/archiwum/module_id/143/przegladrynku-gazu-ziemnego dostęp 19.04.2016

\footnotetext{
${ }^{12} \mathrm{http}: / / \mathrm{www}$.polskielng.pl/lng/terminal-lng-w-polsce/ dostęp 19.04.2016

${ }^{13} \mathrm{http}: / /$ www.rurociagi.com/spis_art/2004_2-3/dekada_LNG.html dostęp 19.04.2016
} 
Powstanie terminalu LNG w Polsce umożliwi odbiór skroplonego gazu ziemnego praktycznie z dowolnego kierunku na świecie. Zróżnicowanie źródeł dostaw przyczyni się do zwiększenia bezpieczeństwa energetycznego kraju. Sumaryczna moc zapowiedzianych terminali eksportowych w Stanach Zjednoczonych i Kanadzie tworzy potencjał do rywalizacji z dotychczasowymi dostawcami surowca. Konkurencja będzie miała wymiar cenowy i może zaowocować powstaniem globalnego rynku LNG. Katar wcale nie musi być jedynym dostawcą LNG do Polski ${ }^{14}$. Rynek gazu płynnego zmienia się w szybkim tempie i do tradycyjnych graczy dołączają inne kraje. Według prognoz amerykańskiej agencji ds. energii, Stany Zjednoczone zaczną eksportować gaz w 2016 roku, a od 2021 będą już eksporterem netto tego surowca. PGNiG nie wyklucza skorzystania z tego źródła dostaw. Spółka w swojej długoletniej strategii przedstawionej pod koniec ubiegłego roku poważnie bierze pod uwagę import skroplonego gazu pochodzącego z niekonwencjonalnych amerykańskich złóż. Argumentem przemawiającym za taka opcją ma być m.in. dywersyfikacje dostaw skroplonego gazu ziemnego do Polski oraz zagospodarowanie potencjału terminalu LNG w Świnoujściu.

\section{GAZ LUPKOWY}

Choć niepewność co do gazu łupkowego w Polsce hamuje rozwój tej gałęzi gospodarki, nie ulega wątpliwości, że gaz ze złóż niekonwencjonalnych zmienia energetykę. To czy zmiany będą miały charakter globalny, zależeć będzie od rozwoju rynku gazu skroplonego na świecie. Latem 2008 r. ceny gazu w USA biły rekordy. Za $1000 \mathrm{~m}^{3}$ "błękitnego paliwa" trzeba było na giełdzie w Nowym Jorku zapłacić 480 dolarów. W tym czasie amerykańscy gazownicy dopiero rozkręcali wiercenia w łupkach i ze złóż w tym skałach pochodziła mniej więcej jedna dwudziesta całego wydobycia gazu w Stanach ${ }^{15}$. Rysunek 6 przedstawia fluktuację cen gazu w USA na przestrzeni lat 2002-2012. Obecnie eksploatacja złóż niekonwencjonalnych $\mathrm{w}$ Stanach Zjednoczonych doprowadziła do konkurencji „gazu z gazem", której efektem jest dramatyczny spadek cen tego surowca w USA ${ }^{16}$.

\footnotetext{
${ }^{14} \mathrm{http}: / /$ www.polskatimes.pl/artykul/76819,pierwsze-dostawy-z-gazoportu-w-2014-r,id,t.html dostęp 19.04.2016

${ }^{15} \mathrm{http} / / /$ wyborcza.biz/Energetyka/1,129200,12887482,Lupki_moga_rozkrecic_gospodarke.html dostęp 20.04.2016

${ }^{16} \mathrm{http}: / /$ weglowodory.pl/gaz-skroplony-z-usa/ dostęp 20.04.2016
} 


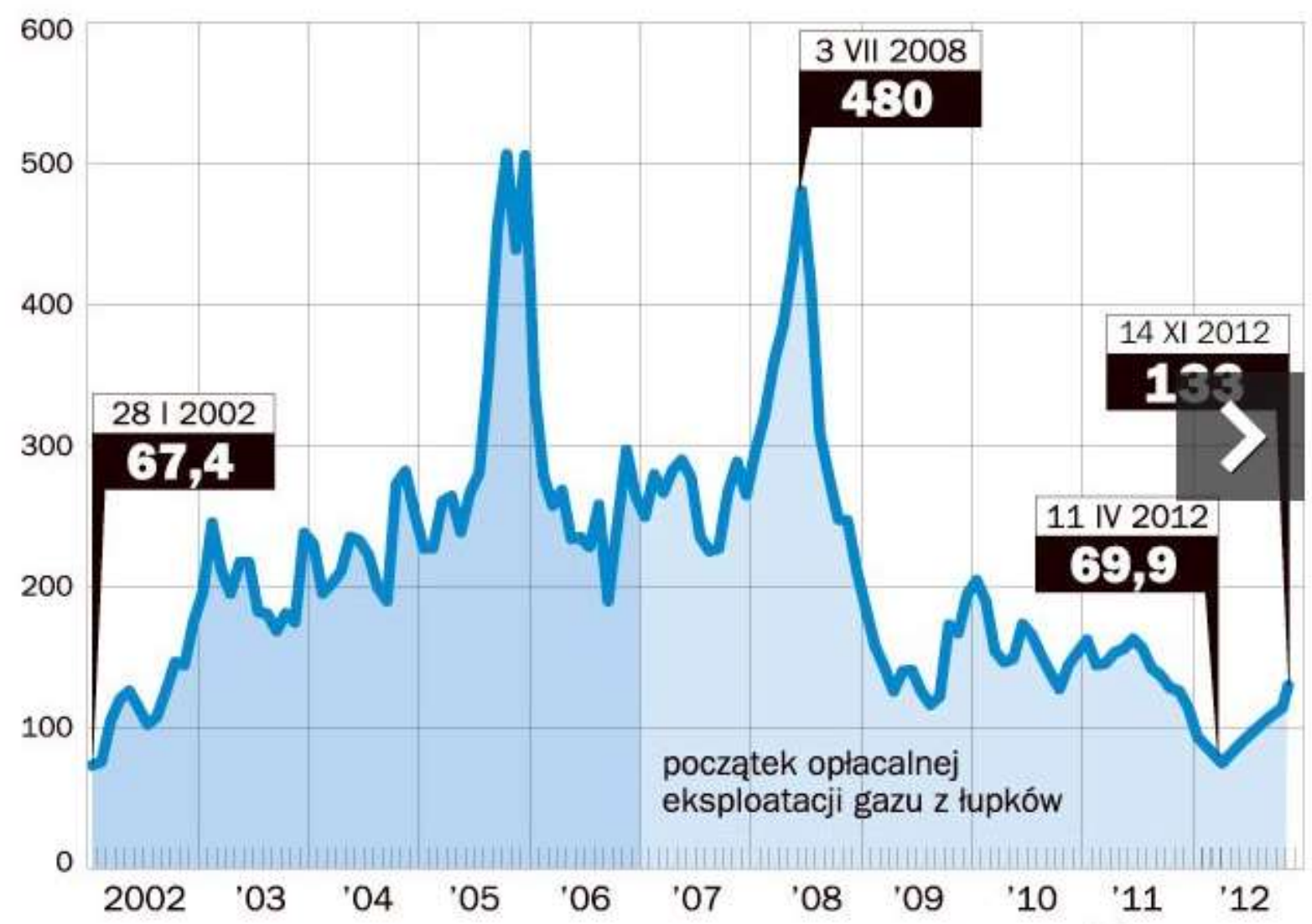

Rys. 6. Ceny gazu w USA (w dol.) za 1 tyś. $\mathrm{m}^{3} \mathrm{z}$ kontraktów terminowych

Źródło: Energy Information Administration, Nymex, www.eia.gov

Gwałtowny spadek cen gazu w Stanach Zjednoczonych poza oczywistym wzrostem konkurencyjności gospodarczej i korzyściami społecznymi wynikającymi z dostępu do taniej energii stworzył także zagrożenia. Najbardziej poszkodowanymi w pierwszej kolejności będą producenci gazu łupkowego, którzy nie będą w stanie pokryć poniesionych nakładów dzięki środkom ze sprzedaży surowca. Wysokie koszty wydobycia przy niskim bądź nawet ujemnym zwrocie z inwestycji doprowadzą do wstrzymania realizacji nowych projektów. W rezultacie spadnie wydobycie, a cena gazu powoli zacznie rosnąc do momentu, aż cyk1 zatoczy koło. Stany Zjednoczone jako „gazowa wyspa” same muszą konsumować wyprodukowany surowiec. Do tej pory było to korzystne dla amerykańskiej gospodarki, lecz w długim okresie konieczne staje się stworzenie mocy eksportowych, które uchronią przed jeszcze większym spadkiem cen gazu, a z drugiej zapewnią bodziec do dalszego rozwoju 
całego przemysłu wydobywczego, który stworzył jedną dziesiątą nowych miejsc pracy powstałych w ubiegłym roku w USA ${ }^{17}$.

W krótkim okresie Polska nie będzie beneficjentem zmian zachodzących na światowym rynku gazu. Czasochłonny rozwój sektora gazu łupkowego z jednej strony oraz uwiązanie długoterminowymi umowami na dostawy surowca z Rosji cementują bieżącą, niekorzystną sytuację. Perspektywiczny wydaje się natomiast rozwój rynku poprzez inwestycje w bloki gazowe, które pomogą Polsce $\mathrm{w}$ uporaniu się $\mathrm{z}$ unijnym pakietem energetycznoklimatycznym oraz stworzą przestrzeń dla nowych dostawców. Publikowane szacunki zasobów gazu w Polsce w naturalny sposób wywołują pytanie o potencjalny poziom wydobycia w Polsce i horyzont czasowy uruchomienia produkcji na skalę przemysłową.

\section{PODSUMOWANIE}

Mimo wielowariantowości podejmowanych działan służących dywersyfikacji dostaw gazu do Polski, Polska nadal jest uzależniona od dostaw gazu z Rosji. Wynika to z zaniedbań, jakich dopuszczono się w minionych latach. Brak dywersyfikacji dostaw gazu ogranicza możliwość tworzenia konkurencyjnego rynku gazu w Polsce. Utrudnia bowiem uprawnionym odbiorcom korzystanie z przysługującego im prawa dostępu do usług przesyłowych (zasada TPA $^{18}$ ). Obecna słaba pozycja negocjacyjna Polski wobec rosyjskiego dostawcy może narazić Polskę na dyktat cenowy ze strony Rosji. Nasz kraj będzie musiał odebrać określone kontraktami ilości gazu niezależnie od potrzeb, po stałych cenach, często wyższych od obecnie stosowanych na rynku wtórnym. Jednocześnie ryzyko wstrzymania dostaw gazu oraz podniesienia ceny może ograniczyć rozwój zastosowań gazu w Polsce. Trzeba jednak podkreślić, że obecne ograniczenia w możliwości pozyskania dodatkowej ilości gazu do Polski chronią pozycję PGNiG SA na krajowym rynku gazu. Brak możliwości technicznych przesłania gazu uniemożliwia nowym dostawcom zaoferowanie odbiorcom przemysłowym dostaw gazu w ramach realizacji zasady TPA. Gaz ziemny staje się coraz bardziej istotnym

\footnotetext{
${ }^{17}$ http://weglowodory.pl...op. cit dostęp 20.04.2016

${ }^{18}$ Zasada TPA (z ang. Third Party Access), czyli zasada dostępu stron trzecich do sieci oznacza możliwość korzystania przez klienta z sieci lokalnego dostawcy energii w celu dostarczenia energii kupionej przez niego u dowolnego sprzedawcy. Lokalny dostawca zobowiązany jest do przesyłu energii kupionej przez znajdującego się na jego obszarze klienta (oczywiście pod warunkiem, że jest to technicznie możliwe).
} 
surowcem energetycznym na świecie, a rynki gazu należą do najszybciej zmieniających się segmentów globalnego handlu paliwami kopalnymi. Starannie analizując wszystkie „za i przeciw”, powinno się kontynuować poszukiwania gazu ziemnego zarówno w jego konwencjonalnych „oswojonych” już złożach, jak i tego uwięzionego w łupkach. Wiele argumentów wskazuje na to, że gaz ziemny jest paliwem najmniej szkodliwym dla środowiska naturalnego, spośród wszystkich surowców energetycznych i jednocześnie najbardziej efektywnym, jakie człowiek odkrył i ma szansę racjonalnie wykorzystać. W celu dywersyfikacji dostaw gazu do Polski konieczne jest zwiększenie technicznych możliwości pozyskania tego surowca (gazoport), a także jednoznaczne określenie wielkości niekonwencjonalnych zasobów gazu w Polsce.

\section{BIBLIOGRAFIA}

\section{Akty prawne}

1. Ustawa z dnia 10 kwietnia 1997 r. Prawo energetyczne, Dz. U. 1997 Nr 54 poz. 348 z późn, zm

2. Polityka energetyczna Polski do 2030 roku, Załącznik do uchwały nr 202/2009 Rady Ministrów z dnia 10 listopada 2009 r., Ministerstwo Gospodarki

\section{Wydawnictwa zwarte:}

1. Malinowski Dariusz, Andrzej Wanok Potentat przez wyzwaniem, Nowy Przemysł nr 9 (125),wrzesień 2008

2. Riedel Rafał, Bezpieczeństwo energetyczne we wspótczesnej securitologii (w:) Bezpieczeństwo energetyczne Europy Środkowej, red. P. Mickiewicz, P. Sokołowska, Wydawnictwo Adam Marszałek, Toruń 2010,

3. Wandzik Andrzej, Gaz jako element bezpieczeństwa energetycznego kraju, Gdańska Fundacja Kształcenia Menedżerów, Warszawa 2008

4. Lewandowska Maria, Gaz spotowy, czyli żaden. Jak doszło do afery z Euralem?, „Nafta \& Gaz Biznes”, grudzień 2003. 


\section{Źródła internetowe:}

1. http://infolupki.pgi.gov.pl/

2. http://tozalezy.pl/

3. http://weglowodory.pl/

4. http://weglowodory.pl/

5. http://wyborcza.biz/Energetyka/

6. http://wydawnictwo.inzynieria.com/

7. http://www.egospodarka.pl/

8. www.eia.gov

9. http://www.pb.pl/

10. http://www.polskatimes.pl/

11. http://www.rmf24.pl/

12. http://www.rurociagi.com/

13. http://www.ure.gov.pl/

14. http://ziemianarozdrozu.pl/ 